\title{
Effects of different soil management practices on soil properties and microbial diversity**
}

\author{
Anna M. Gajda ${ }^{1 *}$, Ewa A. Czyżं, Anthony R. Dexter ${ }^{1}$, Karolina M. Furtak ${ }^{1}$, Jarosław Grzqdziel ${ }^{1}$, \\ and Jadwiga Stanek-Tarkowska
}

\author{
${ }^{1}$ Institute of Soil Science and Plant Cultivation, State Research Institute, Czartoryskich 8, 24-100 Puławy, Poland \\ ${ }^{2}$ Rzeszów University, Department of Soil Science, Environmental Chemistry and Hydrology, Faculty of Biology and Agriculture, \\ Zelwerowicza 8 B, 35-601 Rzeszów, Poland
}

Received July 5, 2017; accepted November 9, 2017

\begin{abstract}
A b s t r a c t. The effects of different tillage systems on the properties and microbial diversity of an agricultural soil was investigated. In doing so, soil physical, chemical and biological properties were analysed in 2013-2015, on a long-term field experiment on a loamy sand at the IUNG-PIB Experimental Station in Grabów, Poland. Winter wheat was grown under two tillage treatments: conventional tillage using a mouldboard plough and traditional soil tillage equipment, and reduced tillage based on soil crushing-loosening equipment and a rigid-tine cultivator. Chopped wheat straw was used as a mulch on both treatments. Reduced tillage resulted in increased water content throughout the whole soil profile, in comparison with conventional tillage. Under reduced tillage, the content of readily dispersible clay was also reduced, and, therefore, soil stability was increased in the toplayers, compared with conventional tillage. In addition, the beneficial effects of reduced tillage were reflected in higher soil microbial activity as measured with dehydrogenases and hydrolysis of fluorescein diacetate, compared with conventional tillage. Moreover, the polimerase chain reaction - denaturing gradient gel electrophoresis analysis showed that soil under reduced tillage had greater diversity of microbial communities, compared with conventionally-tilled soil. Finally, reduced tillage increased organic matter content, stability in water and microbial diversity in the top layer of the soil.

$\mathrm{K}$ e y w o r d s: soil tillage systems, soil water content, soil stability in water, soil enzymatic activity, soil DNA, PCR-DGGE analysis
\end{abstract}

\section{INTRODUCTION}

Interrelated soil physical, chemical and biological properties determine the quality of soil and its function. The role and importance of soil quality for sustainable agricultural

\footnotetext{
*Corresponding author e-mail: Anna.Gajda@iung.pulawy.pl

**Financial support was received from the Programme of the Scientific Network, No. 17/E-184/SN-019/2007, and partly by IUNG-PIB Research Programme $2.5 ; 4.2 ; 1.3 ; 1.4$ and Statute Project 3.1.4 and 2.26.
}

development under environmental protection conditions is receiving increasing attention from both farmers and researchers. In order to have soil with high physical quality, it is necessary to have two main structural features: firstly, the soil must be stable in water, and, secondly, the soil must have a suitable pore size distribution that will enable the soil to absorb, store and release water for plant use (Czyż and Dexter, 2015; Gațe et al., 2004). Such soils will also have a good aeration status and will be more easily penetrable by plant roots. An important part of the pore space in soils with some clay content is the network of micro-cracks that make the soil friable and easy to till over a wide range of water contents (Gațe et al., 2004; Watts and Dexter, 1997). Soil is usually assumed to have 'good' physical quality when it is friable, does not produce clods when tilled, is not hard-setting, is penetrable by plants, is permeable and is stable in water (Dexter, 2002; Gațe et al., 2004; Keller et al., 2007). Clay and organic matter contents play significant roles in the structural stability of soils (Czyż and Dexter 2008, 2009, 2015). Soil organic matter (SOM) is a key attribute of soil quality and affects soil physical, chemical and microbiological properties (Franzluebbers, 2002; Gajda et al., 2017; Gregorich et al., 1994; Six et $a l ., 2002)$. If the clay is not stable, then soil micro-aggregates and aggregates cannot exist (Dexter, 2002; Dexter et al., 2008). When clay disperses, the soil is unstable when wet or in water. On drying, the dispersed clay acts like a cement between the larger soil particles. Therefore,

(C) 2018 Institute of Agrophysics, Polish Academy of Sciences 
a high content of readily dispersible clay results in soil which is both too weak when wet and too strong when dry (Czyż et al ., 2002).

Agricultural management brings about big changes in the soil environment, especially in the ecological pattern of diversity and activity of microbial communities, and in ecosystem functions. Soil microbial biomass and the activities of enzymes have been recommended as potential indicators of changes in soil environment because of their rapid response to changes in soil management, relatively ease of measurement, and high sensitivity to temporary changes in soil environment induced by management and environment factors. Since microbial functional diversity represents many metabolic processes in soil, the activity of at least a few soil enzymes should be measured (Dick et al., 1996; Doran et al., 1996; Nannipieri et al., 2014).

Over the last decade, denaturing gradient gel electrophoresis (DGGE) has become one of the most used techniques for characterizing communities of bacteria inhabiting the soil. The electrophoretic mobility of DNA fragments on polyacrylamide gel, obtained after PCR (polymerase chain reaction - a technique used to amplify a particular fragment of DNA, generating thousands to millions of copies) depends on the nucleotide composition (Muyzer and Smalla, 1998; Nannipieri et al., 2014).

The application of molecular techniques in combination with traditional culture-dependent methods for investigation of diversity of soil microbial communities provides new understanding of the diversity and distribution of microorganisms in soil and their contribution to the quality of agricultural soils. There is growing interest in reduced tillage (RT) with mulching as an alternative to conventional tillage (CT) to better conserve soil organic matter and to maintain good conditions for plant growth in monoculture (Wolińska et al., 2012, 2017).

The aim of this research was to compare the effects of conventional and reduced tillage on soil quality by monitoring changes in some soil properties: physical (water content, soil stability), chemical (organic matter content), biochemical (enzymatic activity) and microbial genetic diversity (PCR-DGGE).

\section{MATERIALS AND METHODS}

The study was done in 2013-2015, on a long-term field experiment started in 2002, at the Experimental Station in Grabów (Mazowieckie voivodeship). This is located in the Central-Eastern part of Poland (51 $21^{\circ} \mathrm{N}, 21^{\circ} 40^{\prime} \mathrm{E}, 166 \mathrm{~m}$ a.s.l.) and belongs to the Institute of Soil Science and Plant Cultivation - State Research Institute (IUNG-PIB) in Puławy. The soil, according to the FAO World Reference Base for Soil Resources (WRB) (FAO, Rome, Italy, 1998), is a Eutric Fluvisol with a loamy sand texture (Polish Society of Soil Science - PTG, 2008). Some characteristics of the soil are given in Table 1.

Winter wheat (var. Jantarka) was grown in monoculture in two tillage systems: 1) conventional (inversion) tillage (CT) with surface mulching (chopped wheat straw) based on mouldboard ploughing to $25 \mathrm{~cm}$ depth and traditional soil management equipment, and 2) reduced (non-inversion) tillage (RT) with surface mulching (chopped wheat straw) based on soil crushing-loosening equipment and a rigid-tine cultivator to $10 \mathrm{~cm}$ depth. The two tillage systems were arranged in a randomized block design in 4 replications, resulting in a total of 8 plots.

T a b l e 1. Chosen physical and chemical properties of the experimental soil $(0-20 \mathrm{~cm}$ depth $)$

\begin{tabular}{|c|c|c|c|c|}
\hline \multirow{2}{*}{ Parameters } & \multirow{2}{*}{ Units } & \multirow{2}{*}{ Depth (cm) } & \multicolumn{2}{|c|}{ Tillage system } \\
\hline & & & conventional (CT) & reduced $(\mathrm{RT})$ \\
\hline \multicolumn{5}{|c|}{ Particle-size distribution (mm) } \\
\hline Sand (2-0.02) & \multirow{3}{*}{$\left(\mathrm{g} 100 \mathrm{~g}^{-1}\right)$} & \multirow{3}{*}{$0-20$} & 76.32 & 76.05 \\
\hline Silt (0.02-0.002) & & & 21.61 & 21.89 \\
\hline Clay $(<0.002)$ & & & 2.07 & 2.06 \\
\hline \multirow{4}{*}{ Soil organic matter } & \multicolumn{3}{|c|}{ Chemical properties } & \\
\hline & \multirow{3}{*}{$\left(\mathrm{g} 100 \mathrm{~g}^{-1}\right)$} & $0-5$ & 1.31 & 1.57 \\
\hline & & $15-20$ & 1.33 & 0.98 \\
\hline & & average & 1.32 & 1.28 \\
\hline $\mathrm{pH}_{\mathrm{KCl}}$ & & \multirow{4}{*}{$0-20$} & 6.20 & 6.40 \\
\hline Available P & $\left(\mathrm{mg} \mathrm{P}_{2} \mathrm{O}_{5} 100 \mathrm{~g}^{-1}\right)$ & & 21.07 & 16.43 \\
\hline Available K & $\left(\mathrm{mg} \mathrm{K}_{2} \mathrm{O} 100 \mathrm{~g}^{-1}\right)$ & & 10.33 & 9.10 \\
\hline Available Mg & $\left(\mathrm{mg} \mathrm{Mg} 100 \mathrm{~g}^{-1}\right)$ & & 7.00 & 8.80 \\
\hline
\end{tabular}


The samples were collected at harvest time in each cropping season at depths of $0-5,5-10,15-20$ and $30-35 \mathrm{~cm}$. The soil physical and chemical properties were measured on soil samples collected from the experimental fields in a disturbed [particle size distribution (PSD), readily dispersible clay (RDC), and soil organic matter (SOM) contents] and undisturbed state [soil water content (SWC) in soil cores, $\mathrm{h}=5 \mathrm{~cm}, \mathrm{dia}=5 \mathrm{~cm}]$ in four replications from 4 depths of soil profile at each field. The soil PSD was measured using the Casagrande aerometric method as modified by Prószyński (Lityński et al., 1976). This enabled the content of clay (mineral particles $<2 \mu \mathrm{m}$ ) to be determined. Soil particle size fractions are named in accordance with the classification of the soil particle size distributions of the Polish Society of Soil Science (PTG, 2008). The SWC was measured using $100 \mathrm{~cm}^{3}$ cylinder samples that were weighed before and after drying at $105^{\circ} \mathrm{C}$ for $48 \mathrm{~h}$. This enabled gravimetric and volumetric water contents and also bulk density to be obtained.

Soil stability in water was measured in terms of readily dispersible clay (RDC) (g $100 \mathrm{~g}^{-1}$ of soil) using a Hach 2100 AN ratio turbidimeter, as described by Czyż and Dexter (2008). Ten replicates were used for each year and depth at each field.

The soil $\mathrm{pH}$ in $\mathrm{KCl}$ was measured potentiometrically (volume fraction 1:2.5 solid:liquid mixture) in a suspension of soil within a $1 \mathrm{~mol} \mathrm{dm}^{-3} \mathrm{KCl}$ solution (International Organization for Standardization - ISO 10390, 2005). Soil organic carbon content (SOC) was measured by wet oxidation using the Tiurin method (Ostrowska et al., 1991). We note that whereas SOC is what is measured in the laboratory, it is soil organic matter (SOM) that governs soil properties in the field. We assume that $\mathrm{SOM}=1.724 \mathrm{SOC}$ as found by Howard (1965). Available P and K were measured by the Egner-Rhiem method and available Mg by the Schachtschabel method (Lityński et al., 1976).

The biological activity was measured in soil samples collected at the same time as the soil for the analysis of physical and chemical properties. Total weight of each representative sample of soil taken from the experimental fields was about $1300 \mathrm{~g}$. After sampling, the soil was immediately placed in double plastic bags, homogenized by hand and stored at $8-10^{\circ} \mathrm{C}$ for transport from the field to the laboratory. In the laboratory, all samples were thoroughly mixed and 10-15 g subsamples were taken to determine the gravimetric water content. The fresh soil samples were sieved through a $2.0 \mathrm{~mm}$ mesh sieve and stored at $4{ }^{\circ} \mathrm{C}$ for further analysis. The analysis of the biochemical quality of soil included activity of dehydrogenases (DEH) measured with 2,3,5-triphenyltetrazolium chloride (TTC) as a substrate (Casida et al., 1964), and hydrolysis of fluorescein diacetate (FDA) by measuring the concentration of fluorescein at $490 \mathrm{~nm}$ released during soil incubation (Schnürer and Rosswall, 1982), as recommended by Dick et al. (1996). The microbiological analyses were made in the Department of Agricultural Microbiology, IUNG-PIB in Puławy, Poland. The enzyme assays were triplicated and controls without substrate were used to correct for background. The activities of the enzymes are reported as $\mu \mathrm{g}$ of product formed per $\mathrm{g}$ dry weight soil per required incubation time $24 \mathrm{~h}$ and/or $\mathrm{h}$. The results are expressed as mean values. The results enable comparison of the $\mathrm{CT}$ and the RT tillage methods. The data were subjected to analysis of variance test (ANOVA) with significance of differences assessed at $p<0.05$. Means were compared by the ANOVA LSD (least significant difference) test.

Total genomic DNA was isolated from soil samples using a FastDNA ${ }^{\mathrm{TM}}$ SPIN Kit for Soil (MP Biomedicals, Santa Ana, CA) according to the manufacturer's instructions. The DNA was extracted from $0.5 \mathrm{~g}$ of fresh soil. To homogenize the samples, the FastPrep ${ }^{\circledR}$ Instrument (MP Biomedicals, Santa Ana, CA) was employed. Isolated DNA was suspended in $50 \mu \mathrm{l}$ DES (DNase/Pyrogen-Free Water). The purity and concentration of the DNA were then measured spectrophotometrically (NanoDrop ${ }^{\mathrm{TM}}$ Lite, Thermo Scientific, Wilmington, DE, USA). A concentration of 2.8$12.8 \mu \mathrm{g} \mathrm{DNA} \mathrm{g}^{-1}$ soil was obtained. Samples were diluted to a final concentration of $10 \mathrm{ng}$ DNA $\mu \mathrm{l}^{-1}$.

After DNA extraction, samples were amplified using two steps of PCR. Reactions were carried out on Thermocycler (Biometra, Germany). The first amplification was done using universal $16 \mathrm{~S}$ ribosomal primers: 27F (AGAGTTTGATCCTGGCTCAG) and 1492R (GGTTACCTTGTTACGACTT) as described by Weisburg et al. (1991). Silver Hot Start PCR MIX LOAD (Syngen) polymerase was used for the reaction. The PCR was performed in a $20 \mu \mathrm{l}$ reaction containing $13.4 \mu \mathrm{l}$ sterile water, $4 \mu \mathrm{l}$ PCR Mix, $2 \mu \mathrm{l}$ DNA sample and $0.3 \mu \mathrm{l}$ of each primer. The PCR reaction was run for about 35 cycles with denaturation temperature at $95^{\circ} \mathrm{C}$ for $30 \mathrm{~s}$, annealing at $52^{\circ} \mathrm{C}$ for $60 \mathrm{~s}$, extension at $72^{\circ} \mathrm{C}$ for $90 \mathrm{~s}$, and a final extension step at $72{ }^{\circ} \mathrm{C}$ for $7 \mathrm{~min}$.

The second PCR was accomplished using primers: GC-338F (GC-clamp- ACTCCTACGGGAGGCAGCAG) and Eub518R (ATTACCGCGGCTGCTGG), as described by Muyzer et al. (1993). This reaction amplified the V3 hypervariable region of the $16 \mathrm{~S}$ rDNA. The PCR was done with an initial denaturation step at $95^{\circ} \mathrm{C}$ for $15 \mathrm{~min}$, followed by 30 cycles of amplification at $95^{\circ} \mathrm{C}$ for $20 \mathrm{~s}, 55^{\circ} \mathrm{C}$ annealing for $30 \mathrm{~s}$, and $30 \mathrm{~s}$ extension at $72^{\circ} \mathrm{C}$, with a final extension step at $72^{\circ} \mathrm{C}$ for $5 \mathrm{~min}$. The PCR products were visualized (for size and quantity) by $1 \%(\mathrm{w} / \mathrm{v})$ agarose gel electrophoresis.

The PCR products were analyzed with DGGE, using the BioRad DCode Universal Mutation Detection System (Bio-Rad, Richmond, CA, USA). Separation of the representative samples was obtained with $8 \%(\mathrm{w} / \mathrm{v})$ polyacrylamide gel containing $35-60 \%$ urea-formamide denaturing gradient. Electrophoresis was performed at 
$60^{\circ} \mathrm{C}$ for $16 \mathrm{~h}$ with a constant voltage of $55 \mathrm{~V}$, in $1 \mathrm{x}$ Trisacetate-EDTA buffer. After the electrophoresis, the gel was stained for 30 min with $1 \times \mathrm{XSyr}^{\circledR}$ Gold (Invitrogen, USA) in $1 \times T A E$ buffer and then visualized under UV light.

The clustering algorithm used to calculate the dendrograms was an unweighted pair group method with arithmetic averages (UPGMA). Quantity One Version 4.6.9. Software (Bio-Rad Richmond, CA, USA) (Fromin et al., 2002) was employed.

\section{RESULTS AND DISCUSSION}

The results for SOM in Table 1 illustrate three main effects. Firstly, the SOM content in the CT treatment is essentially constant with depth within the tilled layer. This is to be expected because of the mixing that occurs during annual ploughing. Secondly, the RT treatment has changed the distribution of SOM with depth. There has been an increase of SOM in the top layer of RT (the layer that is tilled) and a decrease in the layer below the RT layer (i.e. the layer that was ploughed up until 2002, but not subsequently). Thirdly, tillage has produced no significant change in the mean or total amount of SOM. These conclusions are entirely consistent with those of Dimassi et al. (2014) for a soil in northern France.

The effects of tillage systems on soil volumetric water content are clearly demonstrated. The RT system had greater soil water contents than $\mathrm{CT}$ at all four depths studied, especially in the top soil layer (Fig. 1). In the 0-5 and $5-10 \mathrm{~cm}$ layers of the soil, the values of volumetric water content under RT increased by 8.9 and $9.4(\%, \mathrm{v} / \mathrm{v})$, respectively, in comparison with CT. Also, RT increased values of volumetric water content in the $15-20 \mathrm{~cm}$ soil layer by $6.2(\%, v / v)$ relative to CT. However, water content values in the $30-35 \mathrm{~cm}$ soil layer were greater by only $2.9 \%$ under RT relative to CT. In field experiments (2003-2009) at Rogów, in the Lubelskie voivodeship of Poland, on a silt loam soil that had been formed on loess, Czyż and Dexter (2009) reported upon the effect of different tillage practices on physical properties. Herein, the comparison of the effects of different tillage practices on water content after 7 years, showed that soils subjected to reduced tillage and direct drilling both had greater water contents in the top layer, in comparison with the CT system. Małecka et al. (2012) also found that RT and no-tillage (NT) resulted in a higher water content compared with $\mathrm{CT}$. The results after 7 years of experiments with different tillage systems on loamy sand (Albic Luvisols) at the Brody Research Station in Poland showed greater water content in the topsoil (0-5 $\mathrm{cm})$ and in the lower part of the topsoil $(10-20 \mathrm{~cm})$ after RT and NT than after CT. Moreover, the volumetric water content values in the $0-5 \mathrm{~cm}$ soil layer increased by $3.1 \%$ under RT and $5.4 \%$ under NT relative to CT ( $<<0.01$ ). These results are in agreement with water content values in the $10-20 \mathrm{~cm}$ soil layer, which increased by only $1.6 \%$ under RT to CT ( $\mathrm{p}<0.05)$. Mostly, in years with high precipitation, no greater differences in soil water content were observed between CT and RT or NT, but in dry years, greater water content was found after NT (McVay et al., 2006). Also, analysis of the water conditions in the soil profiles by Sławiński et al. (2012) showed that in both a Fluvisol and a Cambisol, during a 3-year research period (20032006), the moisture conditions were better at all depths of the soil profile under RT, compared with CT. The RT system decreased mean values of readily dispersible clay (RDC) throughout the whole profile and increased soil stability in comparison with $\mathrm{CT}$, especially in the top layers $0-5$ and $5-10 \mathrm{~cm}$ (Fig. 2). The soil under CT contained the greatest amounts of RDC. The contents of RDC at $30-35 \mathrm{~cm}$ depth in soil under CT and RT differed only slightly (Fig. 2). Reduced tillage decreased the quantity of readily

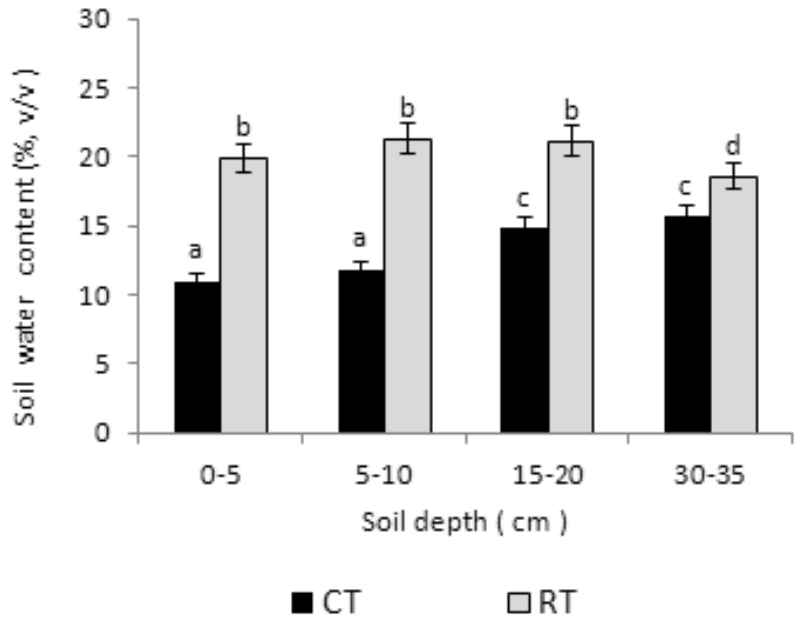

Fig. 1. Mean values of water content $\left(\%, \mathrm{~m}^{3} \mathrm{~m}^{-3}\right)$ at different depths of soil under conventional tillage (CT) and reduced tillage (RT), for the years 2013-2015. a, b, c, d - values marked with different letters are statistically significant at $p \leq 0.05$. Vertical bars represent the standard error (SE).

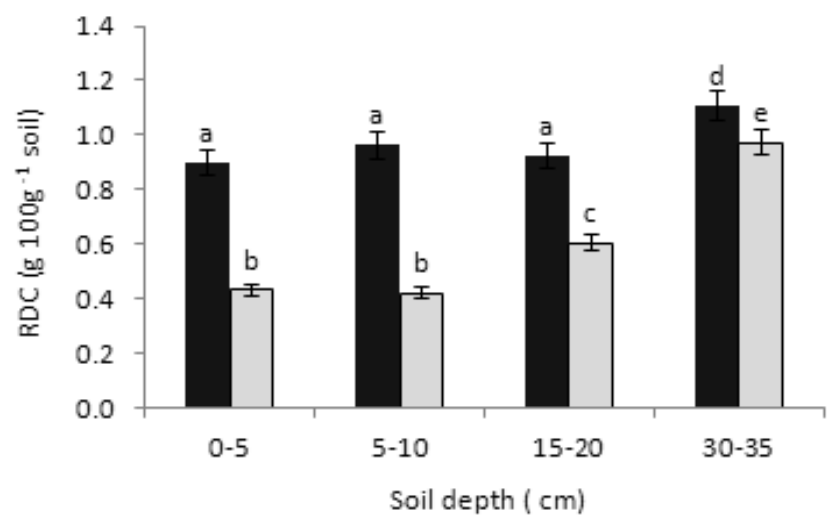

Fig. 2. Mean values of readily dispersible clay (RDC) content in soil under conventional tillage (CT) and reduced tillage (RT) at different depths of soil, for the years 2013-2015. Explanations as in Fig. 1. 
dispersible clay (RDC), and, therefore, increased soil stability, especially in the top layer $5-10 \mathrm{~cm}$ in both soils, in comparison with traditional tillage (Czyż and Dexter 2008, 2009; Dexter and Czyż, 2000; Gațe et al., 2004).

On the basis of the results from field experiments, Czyż and Dexter (2008) concluded that the tillage systems affected the soil physical properties. It was shown that the RT system improved some soil conditions e.g. soil water content and soil stability in water. What is more, the higher concentration of SOM in soil under RT induced a decrease in RDC content, in comparison to that of the CT system. According to Czyż et al. (2002), Czyż and Dexter (2015), Dexter et al. (2008), and Gajda et al. (2016), the total organic $\mathrm{C}$ controls mostly the RDC and then RDC shows a similar outcome to that induced by organic matter, but since it is a complex-bound $\mathrm{C}$, a similar outcome cannot be expected for RDC. As Czyż and Dexter (2015) reported, an increase of SOM has been found to reduce the amount of RDC, in a Polish soil (Dexter and Czyż, 2000), in Romanian soils (Watts et al., 1996), and for a UK soil (Watts and Dexter, 1997).

The SOM content at different depths under CT and RT is shown in Fig. 3. The highest SOM content $\left(1.57{\mathrm{~g} 100 \mathrm{~g}^{-1}}^{-1}\right.$ soil) was in the top layer at the $0-5 \mathrm{~cm}$ depth under RT. The results show that the RT treatment increased significantly the SOM content by $20 \%$ (mostly in the $0-5 \mathrm{~cm}$ soil layer), as compared with CT (1.31 g $100 \mathrm{~g}^{-1}$ soil). Similarly, Franzluebbers (2002) reported that the main differences between CT and NT soil are in the top layers of soil. In a long-term field experiment, Gajda et al. (2017) also showed that RT increased the SOM contents in the top soil layers. Additionally, Małecka et al. (2012) reported that RT and NT favored the surface accumulation of organic $\mathrm{C}$ and total $\mathrm{N}$ in the soil, as well as that of available $\mathrm{K}$ and $\mathrm{Mg}$. In addition, McVay et al. (2006) found that the increase in the organic $\mathrm{C}$ content under RT and NT may contribute to greater aggregate stability and lower sensitivity to erosion by water. As suggested by Urbanek and Horn (2006), in conservation tillage, the accessibility of organic $\mathrm{C}$ for microorganisms and for leaching into deeper horizons of soil is reduced, and less organic $\mathrm{C}$ is removed from the soil than in CT. Dexter et al. (2008) showed that SOM effects on soil physical properties can be related to the clay-size soil fraction.

Work on Polish and French data sets revealed that organic carbon (OC) was complexed with clay for $n=$ clay/ OC ratios higher than $n=10$, which was often observed for arable soils. For pasture soils, clay/OC ratios were typically below 10 (Dexter et al., 2008). Such soils have often been considered as having passed their 'capacity factor' for carbon sequestration (Hassink, 1997). Schjønning et al. (2012) examined whether the clay/OC $=10$ 'saturation' threshold fits with observed data for soil physical behaviour in Denmark. They did this by measuring clay dispersibility in a field with a textural gradient. Their results support

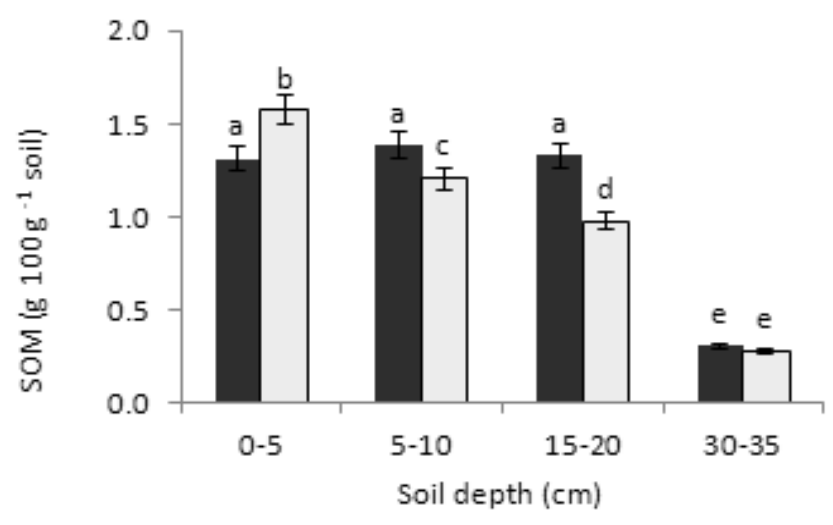

Fig. 3. Mean values of soil organic matter (SOM) content under conventional tillage (CT) and reduced tillage (RT) at different depths, for the years 2013-2015. Explanations as in Fig. 1.

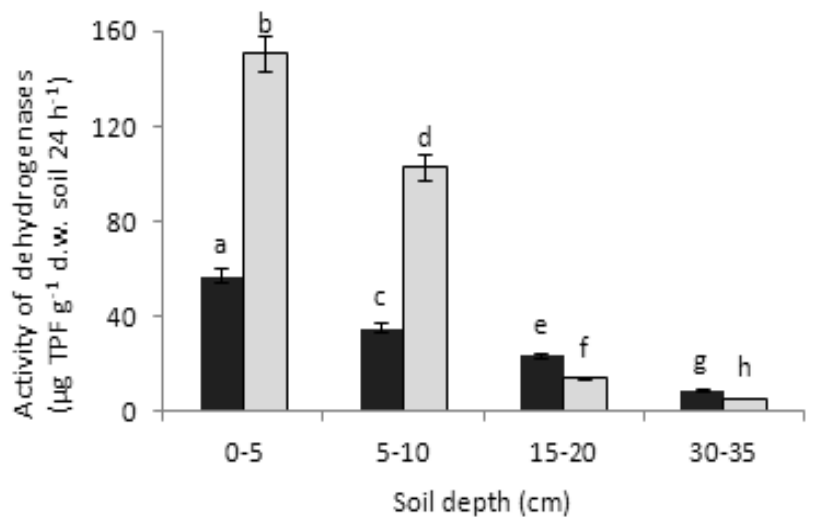

Fig. 4. Effect of different tillage systems on activity of dehydrogenases in soil. Explanations as in Fig. 1.

the concept of differentiating soil content of clay into complexed and non-complexed parts although our data do not indicate an exact clay/OC ratio threshold. These results also illustrate the fact that labile fractions of SOM may play important roles in soil behaviour and in soil quality.

The activity of microorganisms inhabiting the examined soil was measured using the assays of dehydrogenases activity and intensity of FDA hydrolysis, both depended on the tillage treatment and soil depth (Figs 4, 5).

The highest activity of soil microorganisms, measured as dehydrogenases activity, in the soil depth layers of $0-5$ and 5-10 $\mathrm{cm}^{-1}$ under RT reached 150.6 and $102.6 \mu \mathrm{g} \mathrm{TPF} \mathrm{g}^{-1}$ d.w. soil $24 \mathrm{~h}^{-1}$, respectively. In contrast, in the lower layer $(15-20 \mathrm{~cm})$, the average activity of that group of enzymes was 11 and 7 times lower, in comparison, respectively. Similar trends were observed in dehydrogenases activity in soil under CT based on plough, but the obtained values were 2.3 times lower, on average than in a RT soil. What is more, in the deeper layer of soil $(15-20 \mathrm{~cm})$, the dehydrogenases activity in the $\mathrm{CT}$ soil was 1.7 times higher (on average) than in the soil managed under the RT system. Moreover, while the dehydrogenases activity in the subarable soil layer $(30-35 \mathrm{~cm})$ reached the lowest values under 


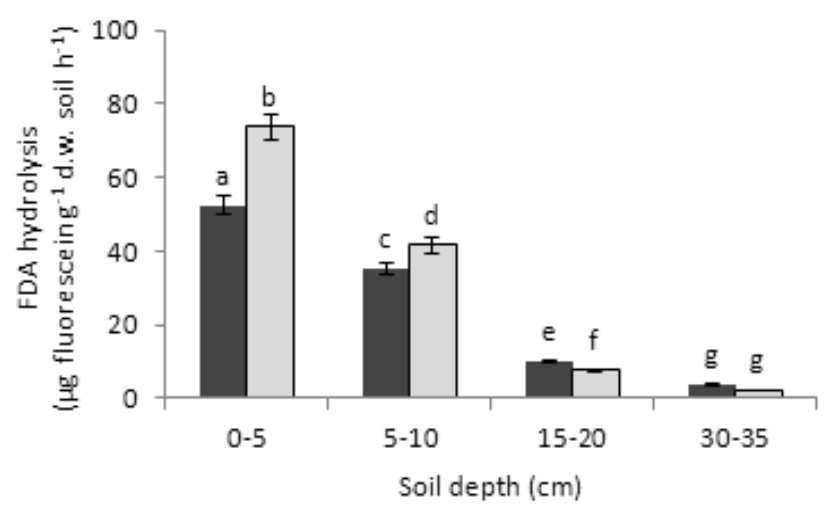

Fig. 5. Effect of tillage systems on microbial hydrolytic activity in soil. Explanations as in Fig. 1.

both RT and CT systems (5.04 and 8.86 $\mu \mathrm{g}$ TPF $\mathrm{g}^{-1}$ d.w. soil $24 \mathrm{~h}^{-1}$, respectively), in the CT soil, the obtained data was 1.8 times higher than in the soil managed under the RT system. The same can be seen in the $15-20 \mathrm{~cm}$ soil layer (Fig. 4). Similar results have been obtained by Alvear et al. (2005), and Marinari et al. (2006), who reported that tillage/residue management (NT and/or organic management) induced significant changes in soil biological activity. This was expressed in the significantly higher enzymatic activity of different soil enzymes (including dehydrogenases), compared to the enzymatic activity measured in a CT soil.

Dehydrogenases are enzymes active in all living, intact cells of microorganisms that are involved in microbial oxidoreductase metabolism and oxidize SOM by transferring hydrogen from the oxidized substrate to acceptor (Gianfreda and Ruggiero, 2006). Therefore, these enzymes are believed to be an accurate measure of the microbial oxidative activity in soil which should have a direct relationship to the whole population of viable microorganisms in soil (Wolińska et al., 2013). Because dehydrogenases are intracellular enzymes, they are more sensitive to natural and anthropogenic stress factors then enzymes associated with colloids. Therefore, the activity of dehydrogenases has often been used as a measure of soil microbial activity. However, dehydrogenase activity may have been underestimated due to competition from alternative hydrogen acceptors within soil (Wolińska and Stępniewska, 2012). Moreover, the study under long-term cultivation of winter wheat by Gajda et al. (2017) demonstrated that soil under RT resulted in greater values of SOM, enzymatic activity, and greater microbial diversity than under CT, especially in the top $(0-5 \mathrm{~cm})$ layer. This suggests a beneficial influence of the RT treatment on the soil environment in comparison with the CT treatment. It has been suggested that a ploughless tillage system creates a less oxidative biochemical environment than plough-based tillage and provides better protection and stabilization of SOM through the activity of microorganisms and soil enzymes (Melero et al., 2009, 2011).
The FDA hydrolysis is also considered as a sensitive and a simple measure of total microbial activity in soil (Dutta et al., 2010). In our studies, the soil enzymatic activity measured as the rate of hydrolysis of FDA showed patterns similar to those of the activity of dehydrogenases (Fig. 5). The highest microorganisms hydrolytic activity was found in the RT soil surface layer $(0-5 \mathrm{~cm})-73.6 \mu \mathrm{g}$ fluorescein $\mathrm{g}^{-1} \mathrm{~d}$.w. soil $\mathrm{h}^{-1}$. In the $5-10 \mathrm{~cm}$ soil layer, the microorganisms hydrolytic activity significantly dropped down, and was about 1.8 times less in relation to that of the surface soil $0-5 \mathrm{~cm}$. Moreover, the microbial activity values in FDA hydrolysis obtained for the RT soil taken from the $15-20 \mathrm{~cm}$ depth layer were about 10 and 5 times less, in comparison with that of the upper layers at 0-5 and 5-10 cm depths, respectively. In the CT soil, the rate of FDA hydrolysis showed similar trends, but the measurements of released fluorescein concentration were 1.4 times less, on average, than in the RT soil. However, in the $15-20 \mathrm{~cm}$ layer, the rate of FDA hydrolysis in the CT soil was 1.3 times greater, on average than in the RT soil. Furthermore, in the sub-arable soil layer $(30-35 \mathrm{~cm})$, the rate of FDA hydrolysis reached the lowest values under both studied tillage systems, but in the CT soil, the obtained value was 1.5 times greater, on average than in soil under RT, these results being similar as in the 15-20 cm layer (Fig. 5). The obtained pattern of the rate of FDA hydrolysis also confirmed the differences in the effects on soil environment between a less-disturbed RT treatment, in comparison with that of the regularly-disturbed CT treatment. An earlier study of Dick et al. (1996) and Leite et al. (2010) also showed the immediate response of soil enzymes to the changes in soil environment induced by tillage system. The authors observed significantly higher activity of microorganisms in FDA hydrolysis in no-till soil, compared with soil tilled conventionally. They noted as well, a decrease of microbial hydrolytic activity with increase in soil depth in both tillage systems. Similarly, Stott and Diack (2004) reported the effects of the soil tillage system on the activity of microorganisms active in hydrolysis of FDA. In NT soil, the values of their measurements of concentration of released fluorescein were 14\% and 30\% higher in relation to soil under tillage systems based on chisel and mouldboard plough, respectively. FDA hydrolysis is carried out by active cells with a variety of enzymes as proteases, lipases and esterases, therefore, it is considered to be a suitable index of the overall enzymes and microbial activity in soil (Green et al., 2006). Tillage practices can affect both the physical and chemical properties of the soil dynamically in space and time, and have consequences on soil biological activity and soil functions. High correlations obtained between soil parameters (SOM, SWC, RDC) and some parameters characterizing the activity of soil microbes (DEH activity and FDA hydrolysis) confirmed the strong mutual dependencies within the properties of the heterogeneous soil complex system (Table 2). These correlations demonstrate the high sensitivity of the 
T a b I e 2. Correlations between some physical and biological properties of soil under different tillage systems

\begin{tabular}{cccc}
\hline \multirow{2}{*}{ Variable } & \multicolumn{2}{c}{ Tillage system } \\
\cline { 3 - 4 } & & $\begin{array}{c}\text { conventional } \\
(\mathrm{CT})\end{array}$ & $\begin{array}{c}\text { reduced } \\
(\mathrm{RT})\end{array}$ \\
\hline \multirow{6}{*}{ SOM } & DEH & $0.56^{*}$ & $0.86^{* *}$ \\
& FDA & $0.64^{*}$ & $0.91^{* *}$ \\
& SWC & $0.64^{*}$ & $0.67^{*}$ \\
SWC & RDC & $-0.92^{* *}$ & $-0.95^{* *}$ \\
& DEH & $0.82^{* *}$ & $0.75^{* *}$ \\
& FDA & $0.78^{* *}$ & $0.66^{*}$ \\
RDC & DEH & $-0.67 *$ & $-0.74 *$ \\
& FDA & $-0.63^{*}$ & $-0.70^{*}$ \\
\hline
\end{tabular}

SOM - soil organic matter content, SWC - soil water content, RDC - readily dispersible clay, DEH - dehydrogenases, FDA fluorescein diacetate. Statistical significance: ${ }^{*} \mathrm{p} \leq 0.05, * * \mathrm{p} \leq 0.01$.

studied parameters to changes in soil, and they show that $\mathrm{SOM}$ is the key for the activity and diversity of microbial communities. Similar results were found by Stutter and Richards (2012).

An analysis of tillage systems gives opportunities to explore the strength of relationships between ongoing soil processes mediated by microbes, the microbial community structure and soil function as a potential to serve as an early indication of soil improvement or degradation. Such knowledge is undoubtedly important for soil quality and sustainable development. Recently proposed culture-independent techniques allow the examination of these relations more precisely than do culture-dependent techniques.

The DNA quantities isolated from soil at different depths are presented in Fig. 6. Significant differences in DNA concentration between RT and CT tillage systems were observed. The highest quantities of extracted DNA (10.3 and $12.8 \mu \mathrm{g} \mathrm{g}^{-1}$ soil) were found in the surface soil (0-5 cm depth) under both treatments, CT and RT, respectively. In both tillage systems, the lowest DNA concentration was in the sub-arable soil at the depth of 30-35 $\mathrm{cm}$ (2.8 and $3.3 \mu \mathrm{g} \mathrm{g}^{-1}$ soil, RT and CT, respectively). The average concentrations of DNA isolated from all the studied soil layers, however, did not differ significantly between applied tillage systems, and reached the level of $8.16 \mu \mathrm{g} \mathrm{g}^{-1}$ soil in $\mathrm{CT}$, and $8.18 \mu \mathrm{g} \mathrm{g}^{-1}$ soil in RT (Fig. 6). Still, differences in the concentrations of isolated DNA across different soils and tillage practices have been found by other authors. The total concentration of DNA isolated from soil by Peixoto et al. (2006) was similar to that in our studies, and was in the approximate range of 5-20 $\mu \mathrm{g} \mathrm{g}^{-1}$ of soil. Furthermore, the DNA concentration in soil (depth $0-20 \mathrm{~cm}$ ) taken from

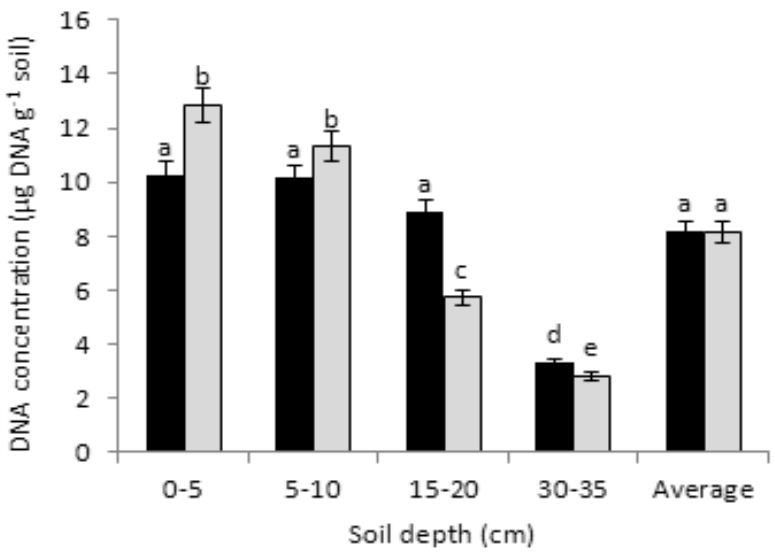

Fig. 6. DNA concentrations in soil under different tillage systems. Explanations as in Fig. 1.

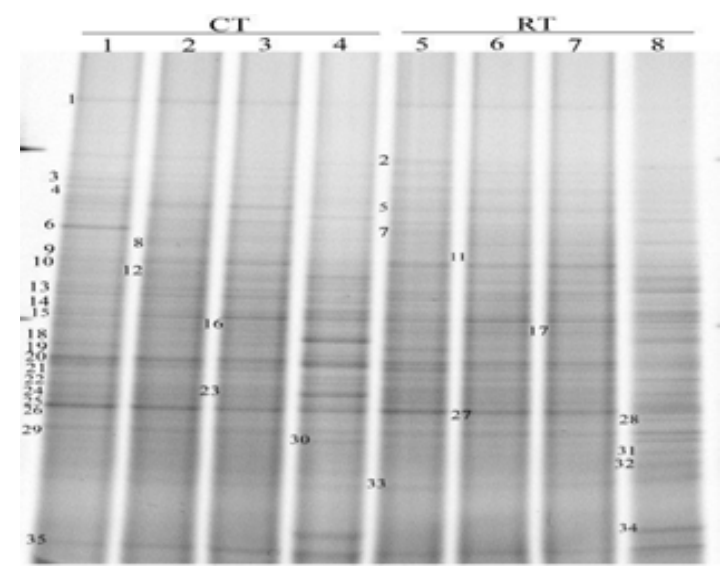

Fig. 7. DGGE band profile of the PCR products from soil under conventional (CT) and reduced (RT) tillage systems. Herein, 35 different DNA profiles are visible. The DGGE bands were analyzed using quantity one software. Explanations: lane No. - soil depth: 1, 5: 0-5 cm; 2, 6: 5-10 cm; 3, 7: 15-20 cm; 4, 8: 30-35 cm.

a hay meadow (Kosiorów Village, South East Poland) and extracted by Wolińska et al. (2013), was at a level of around $107 \mu \mathrm{g} \mathrm{g}^{-1}$ of soil, whereas the concentration of soil DNA obtained by Martin-Laurent et. al. (2001), who used three different methods of isolation, only ranged between 0.2 and $2.5 \mu \mathrm{g} \mathrm{g}^{-1}$ of soil. The bacterial DNA profiles provided by DGGE can be applied as quantitative measures of bacterial diversity (Dilly et al., 2004). Similar to the work of Peixoto et al. (2006), in our study, the effects of CT and RT on soil microbial community structure were determined using PCR-DGGE. Herein, microbial community responses to both tillage systems and soil depth were detected. In both tillage systems, 35 different soil bacteria DNA profiles (Quantity One Software) were detected (Fig. 7). The results of PCR-DGGE analysis revealed 13 to 23 DNA bands per lane in both $\mathrm{CT}$ and RT soil samples (Table 3). This is comparable to that of the study of Xiao et al. (2016) of soil samples taken from two fields located in Yushy Village and Funan Village (Jilin province, China). 
T a b l e 3. Variations seen between DGGE profiles in soil under conventional (CT) and reduced (RT) tillage systems through utilizing quantity one software

\begin{tabular}{|c|c|c|c|c|c|c|c|}
\hline \multicolumn{8}{|c|}{ Tillage system } \\
\hline \multicolumn{4}{|c|}{ conventional (CT) } & \multicolumn{4}{|c|}{ reduced (RT) } \\
\hline \multicolumn{8}{|c|}{ Soil sample number } \\
\hline 1 & 2 & 3 & 4 & 5 & 6 & 7 & 8 \\
\hline \multicolumn{8}{|c|}{ Number of DGGE bands } \\
\hline 20 & 13 & 17 & 17 & 19 & 16 & 20 & 23 \\
\hline
\end{tabular}

Explanations as in Fig. 7.

Herein, the PCR-DGGE results revealed 38-47 bands per lane in every soil sample. In our work, the greatest number of bands was observed in the wells of the RT soil sample. In both RT and CT samples, the least number of bands was observed in the $5-10 \mathrm{~cm}$ depth layer. In the CT sample, most bands were revealed in the well representing the soil taken from the 0-5 cm depth layer (Fig. 7). The DGGE profiles showed a relatively smaller number of clearly-visible, strong bands (strong signals) and much larger numbers of weak bands. Crecchio et al. (2004), suggested that this may imply that a limited number of dominant and ecologically well-adapted types of bacteria, along with several equally abundant bacterial populations, were the common pattern of studied samples of soil under both the RT and CT till- age treatments. Similar results were discussed by Moreno et al. (2009). In our study, the analysis image of DGGE demonstrated that RT soil showed a greater diversity of microbial population. This was represented by 72 bands in total, whereas the CT soil was represented by only 67 bands in total (Table 3). These findings are consistent with those reported by Mathew et al. (2012) and Peixoto et al. (2006). Moreover, Silva et al. (2013) reported that in a long-term field experiment, the DNA profiles representative of each tillage treatment showed differences in soil bacterial diversity, with greater diversity under NT, compared to the other systems studied, inter alia CT.

The dendrogram derived from the $16 \mathrm{~S}$ rDNA DGGE profiles also revealed the effect of tillage system choice on the overall bacterial community structure in different depths of soil profile (Fig. 8).

As indicated, the $16 \mathrm{~S}$ rDNA profiles from the soil tilled in the two different ways were split in two main clusters A and B. Group A is for CT, while group B is for RT. Tillage practices played a major role in the separation of the two main clusters of similarity of the studied soil layers, by changing the richness and the diversity of soil microbial populations (Fig. 8). Soil under systems with lower soil disturbance such as the NT system could also protect microbial habitats by increasing the soil organic matter concentration, enhancing soil moisture content and decreasing temperature variations, all of which affect soil microbial diversity (Silva et al., 2013). Moreno et al. (2009) suggested that

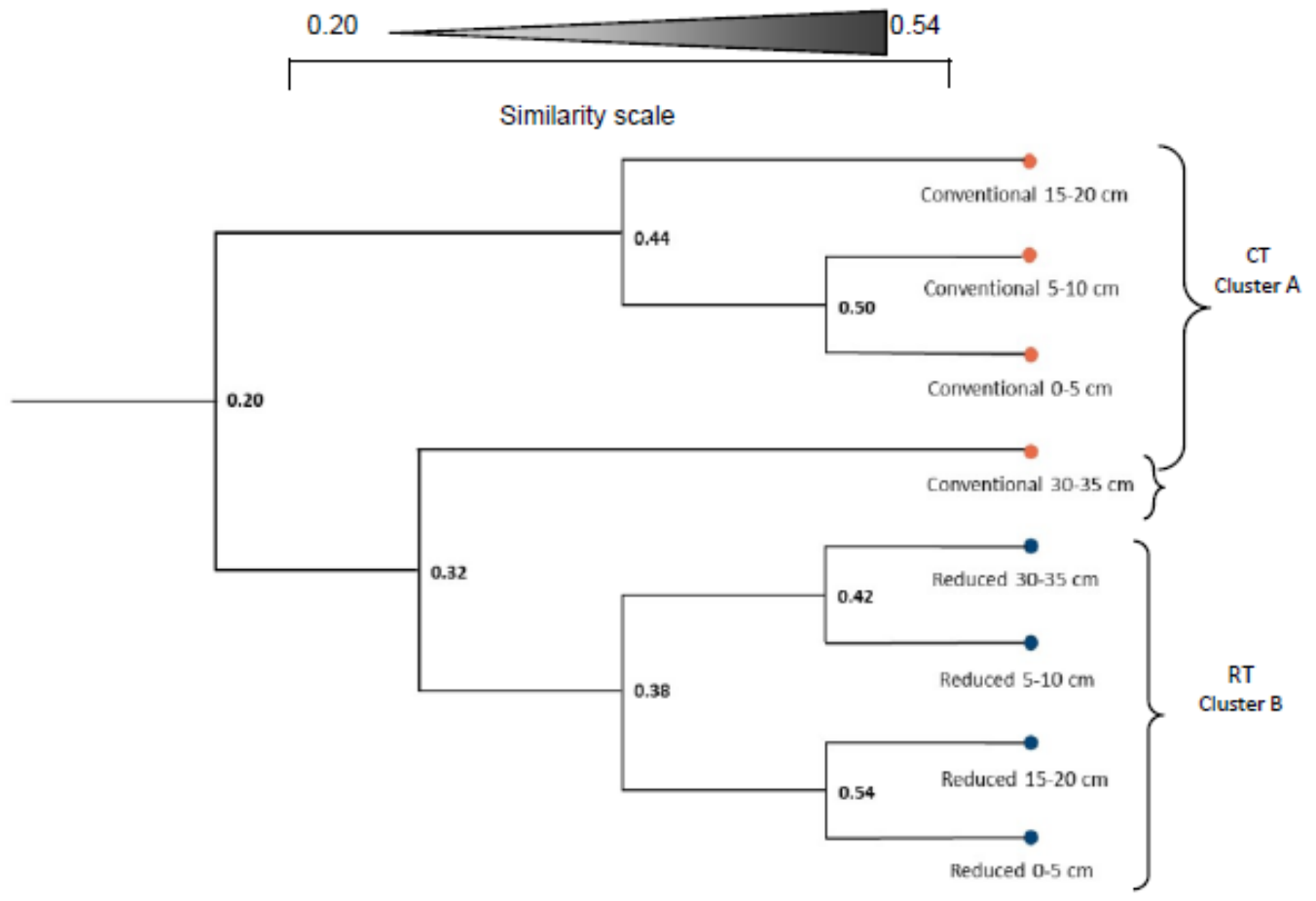

Fig. 8. Cluster analysis of DGGE profiles. The unweighted pair group method with arithmetic averages (UPGMA) dendrogram illustrating the similarity of soil samples under conventional (CT) and reduced (RT) tillage, and how soil microbial functional diversity is affected. Here, larger values represent stronger similarity of microbial communities. 
long-term use of tillage systems would probably influence a shift in soil microbial communities, hence effecting changes in soil physical and chemical properties. With regard to intensive soil tillage based on the plough, such cultivation activity may even eliminate groups of bacteria and may compromise soil functionality.

\section{CONCLUSIONS}

1. Reduced tillage resulted in statistically greater values of soil water content, enzymatic activity and greater microbial diversity than did conventional tillage.

2 . The type of tillage practiced did not affect significantly the total amount of soil oragnic matter, but did change its distribution with depth.

3. Reduced tillage decreased the amount of readily dispersible clay and therefore increased soil stability, especially in the top soil layers $(0-5$ and $5-10 \mathrm{~cm})$, in comparison with conventional tillage.

4. Microbiological activity of soil measured as the activity of dehydrogenases and the intensity of fluorescein diacetate hydrolysis showed similar patterns of behaviour, responding similarly to the tillage system and soil depth. Soil under the long-term reduced tillage showed significantly higher activity of both dehydrogenases and intensity of fluorescein diacetate hydrolysis at the $0-5$ and $5-10 \mathrm{~cm}$ depths than did the same soil under conventional tillage.

5 . The polymerase chain reaction - denaturing gradient gel electrophoresis revealed that most of the 35 bands appeared to be common for the two different tillage systems and soil depths. The genetic diversity of soil microbial communities differed between conventional and reduced tillage in the total number of bands, indicating that the reduced tillage system increased the diversity of microbial communities in the soil.

Conflict of interest: The Authors do not declare conflict of interest.

\section{REFERENCES}

Alvear M., Rosas A., Rouanet J.L., and Borie F., 2005. Effects of three soil tillage systems on some biological activities in an Ultisol from southern Chile. Soil Till. Res., 82, 195-202.

Casida L., Klein D., and Santoro T., 1964. Soil dehydrogenase activity. Soil Sci., 98, 371-376.

Crecchio C., Gelsomino A., Ambrosoli R., Minati J.L., and Ruggiero P., 2004. Functional and molecular responses of soil microbial communities under differing soil management practices. Soil Biol. Biochem., 36, 1873-1883.

Czyż E.A. and Dexter A.R., 2008. Soil physical properties under winter wheat grown with different tillage systems at selected locations. Int. Agrophysics, 22(3), 191-201.

Czyż E.A. and Dexter A.R., 2009. Soil physical properties as affected by traditional, reduced and no-tillage for winter wheat. Int. Agrophysics, 23, 319-326.
Czyż E.A. and Dexter A.R., 2015. Mechanical dispersion of clay from soil into water: readily dispersed and spontaneouslydispersed clay. Int. Agrophys., 29, 31-37.

Czyż E.A., Dexter A.R., and Terelak H., 2002. Content of readily dispersible clay in the arable layer of some Polish soils. In: Sustainable Land Management - Environmental Protection - A Soil Physical Approach (Eds M. Pagliai, R. Jones). Advances GeoEcology, 35, 115-124.

Dexter A.R., 2002. Soil structure: The key to soil function. In: Sustainable land management-environmental protection (Eds M. Pagliai, R. Jones). Advances in Geoecology, 35, 57-69.

Dexter A.R. and Czyż E.A., 2000. Effect of management on the dispersibility of clay in a sandy soil. Int. Agrophysics, 14, 269-272.

Dexter A.R., Richard G., Arrouays D., Czyż E.A., Jolivet C., and Duval O., 2008. Complexed organic matter controls soil physical properties. Geoderma, 144, 620-627.

Dick R.P., Breakwell D.P., and Turco R.F., 1996. Soil enzyme activities and biodiversity measurements as integrative microbiological indicators. In: Methods for Assessing Soil Quality (Eds J.W. Doran, A.J. Jones). SSSA Press, Madison, WI, USA.

Dilly O., Bloem J., Vos A., and Munch J.C., 2004. Bacterial Diversity in Agricultural Soils during Litter Decomposition. Applied and Environ. Microbiol., 70, 1, 468-474.

Dimassi B., Mary B., Wylleman R., Labreuche J., Couture D., Piraux F., and Cohan J-P., 2014. Long-term effect of contrasted tillage and crop management on soil carbon dynamics during 41 years. Agric. Ecosys. Environ., 188, 134-146.

Doran J.W., Sarrantonio M., and Liebig M., 1996. Soil health and sustainability. In: Advances in Agronomy (Ed. D.L. Sparks). Academic Press, San Diego, 56, 1-54.

Dutta M., Sardar D., Pal R., and Kole R.K., 2010. Effect of chlorpyrifos on microbial biomass and activities in tropical clay loam soil. Environ. Monitoring Assessment, 160, 385-391.

FAO, 1998. World reference base for soil resources. World soil resources reports. FAO/ISRIC/ISSS, Rome.

Franzluebbers A.J., 2002. Soil organic matter stratification ratio as in indicator of soil quality. Soil Till. Res., 66, 95-106.

Fromin N., Hamelin J., Tarnawski S., Roesti D., JourdainMiserez K., Forestier N., Teyssier-Cuvelle S., Gillet F., Aragno M., and Rossi P., 2002. Statistical analysis of denaturing gel electrophoresis (DGE) fingerprinting patterns. Environ. Microbiol., 4, 634-643. doi:10.1046/j.14622920.2002.00358.x

Gajda A.M., Czyż E.A., and Dexter A.R., 2016. Effects of longterm use of different farming systems on some physical, chemical and microbiological parameters of soil quality. Int. Agrophys., 30, 165-172, doi: 10.1515/intag-2015-0081

Gajda A.M., Czyż E.A., Stanek-Tarkowska J., Dexter A.R., Furtak K.M., and Grządziel J., 2017. Effects of longterm tillage practices on the quality of soil under winter wheat. Plant Soil Environ., 63, 236-242.

Gațe O.P., Czyż E.A., and Dexter A.R., 2004. Effects of readilydispersible clay on soil quality and root growth. In: Plant Growth in Relation to Soil Physical Conditions (Eds J. Lipiec, R. Walczak, G. Józefaciuk), IA PAS Press, Lublin, Poland. 
Gianfreda L. and Ruggiero P., 2006. Enzyme activities in soil. In: Soil Biology (Eds P. Nannipieri, K. Smalla). SpringerVerlag Berlin Heidelberg, Germany.

Green V.S., Stott D.E., and Diack M., 2006. Assay for fluorescein diacetate hydrolytic activity: optimization for soil samples. Soil Biol. Biochem., 38, 693-701.

Gregorich E.G., Carter M.R., Angers D.A., Monreal C.M., and Ellert B.H., 1994. Towards a minimum data set to assess soil organic matter quality in agricultural soils. Can. J. Soil Sci., 74, 367-385.

Hassink J., 1997. The capacity of soils to preserve organic C and $\mathrm{N}$ by their association with clay and silt particles. Plant Soil, 191, 77-87.

Howard P.J.A., 1965. The carbon-organic matter factor in various soil types. Oikos, 15(2), 229-236.

International Organization for Standardization (ISO), 2005. Soil quality - determination of $\mathrm{pH}$. ISO 10390, Geneva.

Keller T., Arvidsson J., and Dexter A.R., 2007. Soil structures produced by tillage as affected by soil water content and physical quality of soil. Soil Till. Res., 92, 45-52.

Leite L.F.C., Oliveira F.C., Araújo A.S.F., Galvao S.R.S., Lemos J.O., and Silva E.F.L., 2010. Soil organic carbon and biological indicators in an Acrisol under tillage systems and organic management in Northeastern Brazil. Australian J. Soil Res., 48, 258-265.

Lityński T., Jurkowska H., and Gorlach E., 1976. Agricultural Chemical Analyses, Soils and Fertilizers (in Polish). PWN Press, Warsaw, Poland.

Małecka I., Blecharczyk A., Sawinska Z., and Dobrzeniecki T., 2012. The effect of various long-term tillage systems on soil properties and spring barley yield. Turk. J. Agric. For., 36, 217-226, doi:10.3906/tar-1104-20

Marinari S., Mancinelli R., Campiglia E., and Grego S., 2006. Chemical and biological indicators of soil quality in organic and conventional farming systems in Italy. Ecol. Indicators, 6, 701-711.

Martin-Laurent F., Philippot L., Hallet S., Chaussod R., Germon J.C., Soilas G., and Catroux G., 2001. DNA extraction from soils: Old bias for new microbial diversity analysis methods. Appl. Environ. Microbiol., 67(5), 2354-2359.

Mathew R.P., Feng Y., Githinji L., Ankumah R., and Balkcom K.S., 2012. Impact of no-tillage and conventional tillage systems on soil microbial communities. Applied and Environmental Soil Science, Vol. 2012, Article ID 548620, 10 pages, dx.doi.org/10.1155/2012/548620.

McVay K.A., Budde J.A., Fabrizzi K., Mikha M.M., Rice C.W., Schlegel A.J., Peterson D.E., Sweeney D.W., and Thompson C., 2006. Management effects on soil physical properties in long-term tillage studies in Kansas. Soil Sci. Soc. Am. J., 70, 434-438.

Melero R., Lopez-Ganido J., and Murrillo M., 2009. Conservation tillage: short and long term effects on soil carbon fractions and enzymatic activities under Mediterranean conditions. Soil Till. Res., 104, 292-298.

Melero S., Panettieri M., Madejón E., Gómez Macpherson H., Moreno F., and Murillo J.M., 2011. Implementation of chiselling and mouldboard ploughing in soil after 8 years of no-till management in SW, Spain: Effect on soil quality. Soil Till. Res., 112, 107-113.
Moreno B., Garcia-Rodriguez S., Cañizares R., Castro J., and Benítez E., 2009. Rainfed olive farming in south-eastern Spain: Long-term effect of soil management on biological indicators of soil quality. Agr. Ecosys. Environ., 131, 3-4, 333-339.

Muyzer G., deWaal E.C., and Uitierlinden A.G., 1993. Profiling of complex microbial populations by denaturing gradient gel electrophoresis analysis of polymerase chain reactionamplified genes coding for $16 \mathrm{~S}$ rRNA. Appl. Environ. Microbiol., 59(3), 695-700.

Muyzer G. and Smalla K., 1998. Application of denaturing gradient gel electrophoresis (DGGE) and temperature gradient gel electrophoresis (TGGE) in microbial ecology. Antonie Leeuwenhoek, 73, 127-141.

Nannipieri P., 2014. Soil as a biological system and omics approaches. Environmental quality, 13, 61-66, DOI: 10.6092/issn.2281-4485/4541.

Ostrowska A., Gawliński S., and Szczubiałka Z., 1991. Methods of analysis and estimation of soil and plant properties (in Polish). Prot. Environ. Inst. IOOE Press, Warsaw, Poland.

Peixoto R.S., Coutinho H.L.C., Madari B., Machado P.L.O.A., Rumjanek N.G., Van Elsas J.D., Seldin L., and Rosado A.S., 2006. Soil aggregation and bacterial community structure as affected by tillage and cover cropping in the Brazilian Cerrados. Soil Till. Res., 90, 1-2, 16-28.

Polish Society of Soil Science - PSS, 2008. Particle size distribution and textural classes of soils and mineral materials - classification of Polish Society of Soil Science - PSS (in Polish). In: Soil Science Annual, 2009, 60, 2, 5-16.

Schjønning P., de Jonge L.W., Moldrup P., Christensen B.T., and Olesen J.E., 2012. Searching the critical soil organic carbon threshold for satisfactory tilth conditions - test of the Dexter clay: carbon hypothesis. Vadose Zone J., 11, 174-187.

Schnürer J. and Rosswall T., 1982. Fluorescein diacetate hydrolysis as a measure of total microbial activity in soil and litter. Appl. Environ. Microbiol., 43(6), 1256-1261.

Silva A.P., Babujia L.C., Matsumoto L.S., Guimarães M.F., and Hungria M., 2013. Bacterial diversity under different tillage and crop rotation systems in an Oxisol of Southern Brazil. Open Agriculture J., 7, (Suppl 1-M6), 40-47.

Six J., Conant R.T., Paul E.A., and Paustian K., 2002. Stabilization mechanisms of soil organic matter: Implications for C-saturation of soils. Plant Soil, 241, 155-176.

Stawiński C., Cymerman J., Witkowska-Walczak B., and Lamorski K., 2012. Impact of diverse tillage on soil moisture dynamics. Int. Agrophysics, 26, 301-309, doi: 10.2478/ v10247-012-0043-5.

Stott D.E. and Diack M., 2004. Changes in surface soil physical, chemical and biochemical properties under long-term management practices on a temperate mollisol. 13th Int. Soil Conservation Organisation Conf. Conserving Soil and Water for Society: Sharing Solutions, July 4-9, Brisbane, Australia, Paper No. 656, 1-4.

Stutter M.I. and Richards S., 2012. Relationships between soil physicochemical, microbiological properties, and nutrient release in buffer soils compared to field soils. J. Environ. Qual., 41, 2, 400-409, doi: 10.2134/jeq2010.0456.

Urbanek E. and Horn R., 2006. Changes in soil organic matter, bulk density and tensile strength of aggregates after percolation in soils after conservation and conventional tillage. Int. Agrophysics, 20, 245-254. 
Watts C.W. and Dexter A.R., 1997. The influence of organic matter in reducing the destabilization of soil by simulated tillage. Soil Till. Res., 42, 253-275.

Watts C.W., Dexter A.R., Dumitru, E., and Canarache A., 1996. Structural stability of two Romanian soils as influenced by management practices. Land Degradation and Development, 7, 217-238.

Weisburg W.G., Barns S.M., Pelletier D.A., and Lane D.J., 1991. 16S Ribosomal DNA amplification for phylogenetic study. J. Bacteriol., 173(2), 697-703.

Wolińska A., Górniak D., Zielenkiewicz U., Goryluk-Salmonowicz A., Kuźniar A., Stępniewska Z., and Błaszczyk M., 2017. Microbial biodiversity in arable soils is affected by agricultural practices. Int. Agrophysics, 31, 259-271, doi: 10.1515/intag-2016-0040
Wolińska A. and Stępniewska Z., 2012. Dehydrogenase activity in the soil environment. In: Dehydrogenases (Ed. R. Canuto). INTech Publisher, Rijeka, Croatia.

Wolińska A., Stępniewska Z., and Szymańska Z., 2013. Dehydrogenase activity of soil microorganisms and the total DNA level in soil of different use. J. Agric. Sci. Technol., B(3), 613-622.

Wolińska A., Stępniewska Z., Wołoszyn A., and Rzewuska M., 2012. Interrelations between DNA concentration and physicochemical parameters in the loess soil profile. Acta Agrophysica, 19(2), 437-448.

Xiao Ch., Limin Y., Lianxue Z., Cuijing L., and Mei H., 2016. Effects of cultivation ages and modes on microbial diversity in the rhizosphere soil of Panax ginseng. J. Ginseng Res., 40, 28-37. 